\title{
ANDES

www.scielo.cl

\section{Motor skills, physical qualities and sensitive periods in the development schoolchildren}

\author{
Habilidades motoras, cualidades físicas y períodos sensibles en el desarrollo escolar
}

\author{
Héctor Fuentes-Barría ${ }^{\oplus a}$, Raúl Aguilera-Eguía ${ }^{\circledR b}$, Catalina González-Wong ${ }^{\circledR c}$
}

aPrograma Magíster en Ciencias de la Actividad Física y Deportes Aplicadas al Entrenamiento, Rehabilitación y Reintegro Deportivo, Facultad de Salud Universidad Santo Tomás, Chile

bDepartamento de Salud Pública, Facultad de Medicina, Carrera de Kinesiología. Universidad Católica de la Santísima Concepción. Concepción, Chile

'Programa Magíster de Gestión en Salud, Facultad de Salud, Universidad del Desarrollo. Santiago, Chile

\section{Mr. Editor,}

We recently read with interest the work entitled "The Role of Motor Skills in the Sociometric Status and Perceived Social Status of Schoolchildren"1. We congratulate the authors of this study which provide valuable points on the relationship between motor skill the sociometric status and perceived social status in schoolchildren. However, we would like to complement this data with important information.

To make our comments, we must first mention that the motor skills is modulated by the environment, maturation and genetics in the early childhood (4 to 10 years), being the sensitive period for stabilization, fixation and refinement of fundamental skills of locomotion, manipulation and stability that will allow the future promotion of healthy lifestyles product of the better physical condition generated from the greater self-perception and participation in physical activities related to sport, proposing the literature that the evolution fundamental movements related to sport must be accompanied at the same time by development of physical qualities (endurance, strength, speed and muscle flexibility $)^{2,3}$.

On the other hand, the acquisition of movements fundamentals and sport must consider the sensitive phases of chronological and biological development for the provision of optimal stimuli. In this sense, the literature proposes to start with stimuli aimed at the development of muscle flexibility during the stage of acquisition of fundamental movements ( 5 years) and then from the age of 8 generate an emphasis on the development of movement speed, resistance and muscle strength, the latter reaching its maximum susceptibility in adolescen$\mathrm{ce}^{4}$. Finally, we hope these comments contribute to complement the information provided by the authors regarding the importance of generating a estimuli optimal for the developing the motor skills in schoolchildren ${ }^{1}$.

Correspondence:

Héctor Fuentes-Barría

hectorfuentesbarria@gmail.com 


\section{References}

1. de Medeiros $\mathrm{P}$, Almeida Zequinão $\mathrm{M}$, de Paiva Vieira E, et al. The Role of Motor Skills in the Sociometric Status and Perceived Social Status of Schoolchildren. Andes pediatr. 2021; 92(6) (In press)

2. Páez J, MacMillan N, Hurtado J, Yáñez R,
Olate F. Motor behavior according to Body Mass Index in boys and girls aged 6 to 10 years from Viña del Mar, Chile. Cult Cienc y Deporte. 2020; 15(45): 313-9.

3. García-Marín P, Fernández-López $\mathrm{N}$. Association of the fundamental movement skills competence with the extracurricular sports and the body mass index in preschoolers. Retos. 2020; 38: 33-9.

4. Ford P, De Ste Croix M, Lloyd R, et al. The long-term athlete development model: physiological evidence and application. J Sports Sci. 2011;29(4):389402. 